\title{
Integrated Management of Dry Root Rot of Blackgram Caused by Rhizoctonia bataticola
}

\author{
Sunil Kulkarni*, M. Shobharani and Raja \\ Agricultural Research Station, Bidar-585401, University of Agricultural Sciences Raichur, \\ Karnataka, India \\ *Corresponding author
}

\section{A B S T R A C T}

Keywords

Blackgram, Dry root rot, Rhizoctonia bataticola,

Carbendazim and Trichoderma

Article Info

Accepted:

07 July 2019

Available Online:

10 August 2019
The field experiment was conducted for the management of dry root rot disease is caused by Rhizoctonia bataticola in blackgram during 2015 and 2016 Kharif with biocontrol agents and fungicides. Among the different treatments evaluated, T8 treatment (seed treatment (ST) with carbendazim ( $2 \mathrm{~g} / \mathrm{kg}$ of seeds) followed by one foliar spray (FS) with carbendazim $0.1 \%$ ) was found superior in managing the disease by recording lowest disease incidence $(8.38 \%)$ with highest seed yield $(619 \mathrm{~kg} / \mathrm{ha})$. This treatment was followed by T6 treatment (ST with T. viride @ $5 \mathrm{~g} / \mathrm{kg}$ of seeds with one foliar spray of Carbendazim $0.1 \%$ ) with disease incidence of 10.18 and seed yield of $602.22 \mathrm{~kg} / \mathrm{ha}$. However, untreated check recorded highest disease incidence (29.44\%) and lowest seed yield (425.75 kg/ha).

\section{Introduction}

Blackgram (Vigna mungo L.) is an important pulse crop grown throughout India. Blackgram is a rich protein food containing about 25 per cent protein, which is almost three times more than that of cereals. Blackgram supplies a major share of protein requirement of vegetarian population of the country. In India, it occupies an area of 3.5 million ha with a production of 1.5 to 1.9 million tonnes and productivity of $500 \mathrm{~kg} / \mathrm{ha}$. Whereas in Karnataka, blackgram occupies an area of 1.26 lakh ha with the production of 0.64 lakh tonnes and productivity of $508 \mathrm{~kg}$ per ha.
Blackgram is grown in Bidar, Kalaburagi, Raichur, Yadgir, Vijayapur, Dharwad, Bellari and Belagavi districts of Northern Karnataka (Anonymous, 2012).

Blackgram is known to be affected by more than twenty diseases. Among them, anthracnose caused by Colletotrichum lindemuthianum, Cercospora leaf spot caused by Cercospora canescens, powdery mildew caused by Erysiphe polygoni, leaf crinkle disease caused by Leaf Crinkle Virus and a new disease, aerial blight and dry root rot of blackgram caused by Rhizoctonia bataticola is more destructive and known to cause more 
than 60 per cent yield loss. Hence, in the present study an attempt was made to manage this soil borne disease with some bio agents and chemicals.

Root rot disease caused by Macrophomina phaseolina (Tassi) Goid is one of the most important fungal diseases of black gram. It inflicts series economic loss to the crop. It was reported to cause yield loss of 28.6 per cent in black gram. It is an important disease of wide range of crops (Srivastava et al., 2001) particularly in regions with warm and dry weather conditions. M. phaseolina is reported to produce charcoal rot disease over 500 species of plants (Sinclair, 1982). $M$. Phaseolina is primarily soil borne in nature, with heterogeneous host specificity i.e., the ability to infect monocots as well as dicots and non-uniform distribution in the soil (MayekPerez et al., 2001). The pathogen is seedborne and seed-to-seedling transmission of this disease has been documented when infected seeds used (Pun et al., 1998). This pathogen attacks on all parts of plant like, root, stem, branches, petiols, leaves, pods and seeds. The disease symptom starts initially with yellowing and drooping of the leaves and later infected leaves fall off and the plant dies within a week. This disease shows dark brown lesions on the stem at ground level and bark shows shredding symptom. The affected plants can be easily pulled out leaving dried, rotten root portions in the ground. The rotten tissues of stem and root contain a large number of black minute sclerotia (Rangaswami, 1993). Disease incidence is often high when plants are stressed by drought and high temperature. Sclerotia produced in infected plant tissue function as long term survival structures in soil and as primary inoculum. M. phaseolina can be seed-borne and pycnidia and conidia formed on certain hosts enable aerial transmission (from soil conidia spread to leaf and stem by rain and wind) (Pratt et al., 1998) (Soil, seed and air borne) of the disease possesses problems for an effective management disease. Hence, seed treatment can manage seed born pathogen and foliar spray can manage aerial transmitted pathogen.

Therefore, an attempt was made to management the root rot disease of blackgram (Vigna mungo L) caused by Macrophomina phaseolina (Tassi) Goid using bioagents and fungicides.

\section{Materials and Methods}

The field experiments were conducted for two consecutive years during kharif 2015 and 2016 at Agricultural Research Station Bidar. The experiment was laid out in Randomized block design with nine treatments replicated thrice (as detailed in Table 1). Blackgram var. DU-1 was sown at $30 \mathrm{~cm} \times 10 \mathrm{~cm}$ spacing and all the recommended package of practices was followed to raise the crop, except for disease management. Observations on per cent disease incidence were recorded at the end of cropping season. The seed yield was recorded plot wise at the time of harvest and converted in to hectare basis. The data thus collected were subjected to analysis of variance after making necessary transformation.

\section{Percent disease incidence}

Disease incidence (\%) was calculated by counting the number of plants infected and total number of plants in an experimental plot (for each treatment) using the formula given by Vincent (1947).

Percent disease incidence $(P D I)=\frac{\text { Number of infected plants in a plot }}{\text { Total number of plants in plot }} X 100$

\section{Results and Discussion}

The present investigation was carried out using bio-agents and fungicides with different 
combinations to manage dry root rot of blackgram for two consecutive years. The pooled results of the first and second year revealed that $\mathrm{T} 8$ treatment (seed treatment (ST) with carbendazim @ $2 \mathrm{~g} / \mathrm{kg}$ of seeds followed by one foliar spry (FS) at the time when diseases symptoms were noticed with carbendazim $(0.1 \%)$ found significantly superior in managing the disease by recording least disease incidence $(8.38 \%)$ with highest seed yield of $(619 \mathrm{~kg} / \mathrm{ha})$ compared to untreated check which recorded highest dry root rot incidence (29.44\%) and lowest seed yield $(425.75 \mathrm{~kg} / \mathrm{ha})$. This treatment was followed by $\mathrm{T} 6$ treatment (ST with $T$. viride (5 $\mathrm{g} / \mathrm{kg})$ - FS with Carbendazim (0.1 \%) with disease incidence of 10.18 per cent and seed yield of $602.22 \mathrm{q} / \mathrm{ha}$.

The next best treatments were T7 Treatment (ST with $P$. fluorescens $(5 \mathrm{~g} / \mathrm{kg})+$ FS with Carbendazim (0.1\%), T4 Treatment (ST with T. viride $(5 \mathrm{~g} / \mathrm{kg})+$ soil application $(\mathrm{SA})$ of Trichodrema $2.5 \mathrm{~kg} / 250 \mathrm{~kg}$ FYM) and T5 (ST with $P$. fluorescens $(5 \mathrm{~g} / \mathrm{kg})+$ SA of $P$. fluorescens $2.5 \mathrm{~kg} / 250 \mathrm{~kg}$ FYM) with dry root rot incidence of $12.88 \%, 13.30 \%$ and $15.25 \%$ respectively and seed yield of $576.06 \mathrm{~kg} / \mathrm{ha}$, $571.13 \mathrm{~kg} / \mathrm{ha}$, and $551.13 \mathrm{~kg} / \mathrm{ha}$ respectively. The highest, per cent reduction in disease incidence of 71.53 per cent was notice in T8 treatment (ST with Carbendazim $(2 \mathrm{~g} / \mathrm{kg}$ ) followed by FS with Carbendazim $(0.1 \%)$. This is followed by T6 treatment (ST with $T$. viride $(5 \mathrm{~g} / \mathrm{kg})$ followed by $\mathrm{FS}$ with Carbendazim $(0.1 \%)$ and $\mathrm{T} 7$ treatment (ST with $P$. fluorescens $(5 \mathrm{~g} / \mathrm{kg})$ followed by FS with Carbendazim $(0.1 \%)$ with per cent reduction in disease incidence of 65.42 per cent and 56.25 per cent respectively. The next best treatments were T4 treatment (ST with $T$. viride $(5 \mathrm{~g} / \mathrm{kg})+\mathrm{SA}$ of Trichodrema 2.5 $\mathrm{kg} / 250 \mathrm{~kg}$ FYM, T5 treatment (ST with $P$. fluorescens $(5 \mathrm{~g} / \mathrm{kg})+\mathrm{SA}$ of $P$. fluorescens $2.5 \mathrm{~kg} / 250 \mathrm{~kg}$ FYM), T1 treatment (ST with Trichoderma viride (5 $\mathrm{g} / \mathrm{kg}$ seeds) with per cent reduction in disease incidence of 54.82 , 48.20, 40.63 per cent respectively.

\section{B: C ratio}

Benefit cost ratio gives information on whether the technology is economically viable in the farmer's fields or not. Hence, benefit cost ratio is an important parameter for recommendation of any treatment for successful management of plant diseases. In the present study, highest $\mathrm{BC}$ ratio (2.44) was recorded in the T8 treatment (ST with carbendazim $(2 \mathrm{~g} / \mathrm{kg})+\mathrm{FS}$ carbendazim $(0.1 \%)$ and was followed by T6 treatment (ST with $T$. viride $(5 \mathrm{~g} / \mathrm{kg})+$ FS Carbendazim $(0.1$ $\%$ ) with $\mathrm{BC}$ ratio of 2.37. However, untreated control recorded lowest $\mathrm{B}$ : $\mathrm{C}$ ratio of 1.7.

In the present study, seed treatment with carbendazim $(2 \mathrm{~g} / \mathrm{kg})$ or $T$. viride $(5 \mathrm{~g} / \mathrm{kg})$ or $P$. fluorescens $(5 \mathrm{~g} / \mathrm{kg})$ followed by foliar spray with carbendazim $(0.1 \%)$ was found very effective in management of dry root rot of blackgram caused by Rhizoctonia bataticola. These findings are in accordance with Kumar et al., (2011) who reported that, Bavistin and Vitavax were effective in inhibiting the growth of $R$. bataticola and reducing the incidence of jatropha root rot. These fungicides resulted in $100 \%$ inhibition of mycelial growth at $50 \mathrm{ppm}$. Seed treatment with Bavistin and its soil drenching caused the least pre-emergence $(16.7 \%)$ and postemergence mortalities (10.1\%). Trichoderma harzianum showed the highest mycelial growth inhibition (58.9 \%) against $R$. bataticola. Bavistin alone at $2 \mathrm{~g} \mathrm{~kg}-1$ seed was found to be the most effective treatment with $36.3 \%$ reduction in root rot. Integrated methods showed higher disease reduction compared with single method. Bavistin (2 g $\mathrm{kg}-1$ seed $)+$ neem extract $(20 \%)$ was the most effective treatment with $67.3 \%$ reduction followed by $T$. harzianum (15 g kg-1 seed) + Bavistin (54.2\%). 
Table.1 Integrated management of dry root rot of blackgram during 2015-16 and 2016-17 (Pooled analysis)

\begin{tabular}{|c|c|c|c|c|c|}
\hline $\begin{array}{l}\text { Treatment } \\
\text { No. }\end{array}$ & Treatments & $\begin{array}{c}\text { Dry root rot } \\
\text { disease } \\
\text { incidence }(\%)\end{array}$ & $\begin{array}{c}\text { Dry root rot } \\
(\%) \\
\text { reduction } \\
\text { over control }\end{array}$ & $\begin{array}{l}\text { Yield } \\
\text { (kg/ha) }\end{array}$ & BCR \\
\hline $\mathbf{T}_{1}$ & ST with Trichoderma viride (5 $\mathrm{g} / \mathrm{kg}$ seeds) & $\begin{array}{c}17.48 \\
(24.68)\end{array}$ & 40.63 & 516.13 & 2.06 \\
\hline $\mathbf{T}_{2}$ & $\begin{array}{l}\text { ST with Pseudomonas fluorescens (5 } \mathrm{g} / \mathrm{kg} \\
\text { seeds) }\end{array}$ & $\begin{array}{c}19.13 \\
(25.91)\end{array}$ & 35.02 & 501.00 & 2.00 \\
\hline $\mathbf{T}_{3}$ & ST with Carbendazim (2 g/kg seeds) & $\begin{array}{c}18.30 \\
(25.30)\end{array}$ & 37.84 & 491.83 & 1.97 \\
\hline $\mathbf{T}_{4}$ & $\begin{array}{l}\text { ST with } T \text {. viride }(5 \mathrm{~g} / \mathrm{kg})+\text { SA of Trichodrema } \\
2.5 \mathrm{~kg} / 250 \mathrm{~kg} \text { FYM }\end{array}$ & $\begin{array}{c}13.30 \\
(21.36)\end{array}$ & 54.82 & 571.13 & 2.20 \\
\hline $\mathbf{T}_{5}$ & $\begin{array}{l}\text { ST with } P \text {. fluorescens }(5 \mathrm{~g} / \mathrm{kg})+\mathrm{SA} \text { of } P \text {. } \\
\text { fluorescens } 2.5 \mathrm{~kg} / 250 \mathrm{~kg} \mathrm{FYM}\end{array}$ & $\begin{array}{c}15.25 \\
(22.99)\end{array}$ & 48.20 & 551.13 & 2.12 \\
\hline $\mathbf{T}_{6}$ & $\begin{array}{l}\text { ST with } T \text {. viride }(5 \mathrm{~g} / \mathrm{kg}) \text { followed by FS with } \\
\text { Carbendazim }(0.1 \%)\end{array}$ & $\begin{array}{c}10.18 \\
(18.56)\end{array}$ & 65.42 & 602.22 & 2.37 \\
\hline $\mathbf{T}_{7}$ & $\begin{array}{l}\text { ST with } P \text {. fluorescens }(5 \mathrm{~g} / \mathrm{kg}) \text { followed by FS } \\
\text { with Carbendazim }(0.1 \%)\end{array}$ & $\begin{array}{c}12.88 \\
(21.03)\end{array}$ & 56.25 & 576.06 & 2.27 \\
\hline $\mathbf{T}_{8}$ & $\begin{array}{l}\text { ST with Carbendazim }(2 \mathrm{~g} / \mathrm{kg}) \text { followed by FS } \\
\text { with Carbendazim }(0.1 \%)\end{array}$ & $\begin{array}{c}8.38 \\
(16.76)\end{array}$ & 71.53 & 619.00 & 2.44 \\
\hline \multirow[t]{3}{*}{$\mathbf{T}_{9}$} & Control & $\begin{array}{c}29.44 \\
(32.85)\end{array}$ & 0 & 425.75 & 1.70 \\
\hline & S. Em. \pm & 0.56 & & 3.95 & \\
\hline & CD at $5 \%$ & 1.67 & & 11.84 & \\
\hline
\end{tabular}

*Note ST: seed treatment, FS: Foliar spry and SA: Soil application 
Further, Sowmya Tetali et al., (2015) reported that seed treatment + soil application with combination of both $T$. viride isolates significantly reduced the dry root rot of blackgram per cent disease incidence of 5.60 which accounted 88.79 per cent reduction over control. Lalita Lakhran and Ahir (2018) reported that in dry root rot of chickpea Maximum disease control over check was recorded with carbendazim (75.39 \%), followed by carbendazim + mancozeb $(68.00 \%)$. The observations made in the present study corroborate with the results by other researchers (Ramadoss and Sivaprakasam (1994), Prajapati et al., (2002) and Sangappa and Mallesh (2016).

Khan et al., (2012) reported that indofilm-45, Bavistin, companion, copperoxycloride and Benelate were completely inhibited the growth of the fungus on potato dextrose agar medium. The results obtained are in agreement with finding of Singh et al., (1993). Further, three bio-control agents were evaluated in laboratory condition Trichoderma viride, Trichoderma harzinum and pseudomonas Fleuresecense, among them Trichoderma viride showed best performance against the pathogen, Rhizoctonia bataticola, followed by pseudomonas fluorescence, which also checked the fungus growth to some extant similar finding were also reported by Singh et al., (2006).

In recent years cultivation of blackgram has been decreased due to major constraint of dry root rot disease. In the present study ST with carbendazim ( $2 \mathrm{~g} / \mathrm{kg}$ of seeds) followed by FS carbendazim $(0.1 \%)$ or ST with $T$. viride $(5 \mathrm{~g} / \mathrm{kg}$ of seeds) followed by FS Carbendazim $(0.1 \%)$ was found most effective in managing dry root rot disease in blackgram and recorded highest yield. Hence, these treatments can be recommended for the management of the dry root rot disease of blackgram.

\section{References}

Anonymous, 2018. Area, production and productivity of major pulses. http://agropedia.iitk.ac.in.

Kaushik, C. D., Chand and Saryavir, J. N., 1987. Seed borne nature of Rhizoctonia bataticola causing leaf blight of mung bean. Indian J Mycol Plant Pathol. 17: 154-157.

Khan, R. A., Bhat, T. A. and Krishan Kumar, 2012. Management of Chickpea (Cicer arietinum L.) Dry root Rot Caused by Rhizoctonia bataticola (Taub.) Butler. International Journal of Research in Pharmaceutical and Biomedical Sciences. 3 (4): 1539-1548.

Kumar, S., Sharma, S., Pathak, D.V. and Beniwal, J., 2011. Integrated management of jatropha root rot caused by rhizoctonia bataticola. Journal of Tropical Forest Science, 23(1): 35-41.

Lalita Lakhran and Ahir, R. R., 2018. In-vivo evaluation of different fungicides, plant extracts, bio-control agents and organics amendments for management of dry root rot of chickpea caused by Macrophomina phaseolina. Legume Research. 3939, 1-6.

Mayek-Perez N, Lopez-Castaneda, C., Gonzalez-Chavira, M., GarciaEspinosa, R., Acosta-Gallegos, J. M., De-la-vega, O., and Simpson, J., 2001. Variability of Mexican isolates of Macrophomina phaseolina based on pathogenesis and AFLP genotype. Plant Pathol. 59 (5): 257- 264.

Prajapti, R. K., Gangwar, R. K., Srivasta, S. S. L., and Shahid Ahamad. 2002. Efficacy of fungicides, non- target pesticides and bioagents against the dry root rot of chickpea. Annals of Pl. Prot. 10(1): 154-155.

Pratt, R. G., McLaughlin, M. R., Pederson, G. A., and Rowe, D. E., 1998. Pathogenicity of Macrophomina 
phaseolina to mature plant tissues of alfalfa and white clover. Plant Dis. 82: 1033-1038.

Pun, K. B., Sabitha, D., and Valluvaparidasan, V., 1998. Studies on seed-borne nature of Macrophomina phaseolina in okra. Plant Dis Res. 3: 249-90.

Ramadoss, S., and Sivaparakasam K., 1994. Effect of seed treatment with fungicides and insecticides on the control of root rot and stem fly on cowpea. Madras Agric. J. 80: 618-620.

Rangaswami, G., 1993. Diseases of crop plants in India. Prentice Hall of India Pvt. Ltd., New Delhi, India. 520.

Sangappa, G., Mallesh, S. B., 2016. Effect of bioagents and chemicals for the management of aerial blight and dry root rot of blackgram incited by Rhizoctonia bataticola. International Journal of Plant Protection. 9(2) 424429.

Sinclair, J. B., 1982. Compendium of soybean diseases, 2nd ed. American Phyto Pathological Society. Pp. 104.
Singh K. and Singh, A.K. (2006). Seed mycoflora of chickpea and their management. Abstracts National symposium on Indian society of mycology and plant pathology. Pp. 4248. 34.

Singh, B.K., Srivastava, M. and Narain, U. (2003). Evaluation of biogents Rhizoctonia bataticola causing chickpea dry root rot. Department of plant pathology, C.S. Azad Univ. of Agric. and Tech., Kanpur farm Sci. J. 12: 4849.

Sowmya Tetali., Karpagavalli, S., and Lalitha Pavani, S., 2015. Management of dry root rot of blackgram caused by Macrophomina phaseolina (Tassi) Goid. Using bio agent. Plant Archives. 15(2): 647-650.

Srivastava, A. K., Singh, T., Jana, T. K., and Arora, D. K., 2001. Microbial colonization of Macrophomina phaseolina and suppression of charcoal rot of chickpea. In Microbes and Plants, Sinha A (e d). Vedams eBooks (P) Ltd, New Delhi. 269-319.

\section{How to cite this article:}

Sunil Kulkarni, M. Shobharani and Raja. 2019. Integrated Management of Dry Root Rot of Blackgram Caused by Rhizoctonia bataticola. Int.J.Curr.Microbiol.App.Sci. 8(08): 853-858. doi: https://doi.org/10.20546/ijcmas.2019.808.098 